\title{
Quantitative assessment of caveolin-I GI47/3A polymorphism and cancer susceptibility in the Asian population
}

This article was published in the following Dove Press journal:

OncoTargets and Therapy

10 March 2016

Number of times this article has been viewed

\author{
Jianjun Tangl,* \\ Gang Wang ${ }^{2, *}$ \\ Qiang $\mathrm{Li}^{\prime}$ \\ Rongfeng Song' \\ 'Department of Gastroenterology, \\ Cancer Hospital of Jiangxi \\ Province, Nanchang, Jiangxi, ${ }^{2}$ State \\ Key Laboratory of Oncology in \\ South China, Sun Yat-Sen University \\ Cancer Center, Guangzhou, \\ People's Republic of China \\ *These authors contributed equally \\ to this work
}

Purpose: The relationship between caveolin-1 (CAV1) G14713A polymorphism and cancer susceptibility remains inconclusive. The current meta-analysis was performed on the basis of a systematic search in electronic databases for a more precise estimation of the associations.

Methods: Odds ratio (OR) with 95\% confidence interval (CI) was used to estimate the pooled effect.

Results: A total of 12 studies including 4,994 cases and 5,606 controls were involved in this meta-analysis. In the overall analysis, CAV1 G14713A polymorphism was significantly associated with an increased risk of cancer (A vs G: OR $=1.77,95 \% \mathrm{CI}: 1.49-2.10, P_{\text {het }}<0.01$; $[\mathrm{AA}+\mathrm{AG}]$ vs GG: $\mathrm{OR}=2.03,95 \% \mathrm{CI}: 1.64-2.53, P_{\text {het }}<0.01 ; \mathrm{AA}$ vs $[\mathrm{AG}+\mathrm{GG}]: \mathrm{OR}=1.72$, 95\% CI: $1.40-2.12, P_{\text {het }}<0.01$; AA vs GG: OR $=2.24,95 \%$ CI: $1.69-2.98, P_{\text {het }}<0.01$; AG vs GG: $\left.\mathrm{OR}=1.98,95 \% \mathrm{CI}: 1.62-2.41, P_{\text {het }}<0.01\right)$. Subgroup analysis by cancer type showed that $C A V 1 \mathrm{G} 14713 \mathrm{~A}$ polymorphism was associated with an increased risk of digestive system cancer and other cancer types.

Conclusion: Our findings suggest that CAV1 G14713A polymorphisms may modify the risk of cancer, especially digestive system cancer. However, further well-designed studies are warranted to validate this association.

Keywords: caveolin-1, polymorphism, cancer, susceptibility

\section{Introduction}

Annual cancer incidence and mortality continue to rise worldwide. There were $\sim 12.7$ million new cases and 7.6 million new deaths in $2008 .{ }^{1}$ Although the pathogenetic mechanism of cancer has not been fully understood, extensive evidence has indicated the important roles of polymorphisms in the key genes during the process of carcinogenesis. ${ }^{2-4}$ Screening and identification of single nucleotide polymorphisms that are related to cancer susceptibility would greatly benefit individuals at high risk of cancer in the early prevention and treatment settings.

Caveolin-1 (CAV1) is a member of the caveolin family of proteins and has been proved to modulate multiple cancer-associated processes, including cellular transformation, tumor growth, cell migration and metastasis, cell death and survival, and angiogenesis in a number of signaling pathways. ${ }^{5-7}$ Thus, CAV1 is thought to play an important role in tumor development and progression. The CAV1 gene is located on the human chromosome 7q31.1 and has some potentially functional polymorphisms identified. Among these polymorphisms, the associations of CAV1 G14713A polymorphism and cancer susceptibility have been widely investigated; however, results are conflicting. ${ }^{8-19}$ For instance, Liu et al reported
Correspondence: Rongfeng Song Department of Gastroenterology, Cancer Hospital of Jiangxi Province, 519 Beijing Road, Nanchang, Jiangxi Province 330029, People's Republic of China Email rongfengsong1975@163.com cc. permission from Dove Medical Press Limited, provided the work is properly atribibuted. Permisisions beyond the scope of the License are administered by Dove Medical Press Limited. Information on how to request permisision may be found at ht htp:///www.doveperess.com/permisisions.php 
significant positive associations between CAV1 G14713A polymorphism and the risk of breast cancer. ${ }^{16}$ However, Wu et al reported no significant association between $C A V 1$ G14713A polymorphism and risk of prostate cancer. ${ }^{14}$ Based on these observations, we conducted the present meta-analysis to clarify the role of CAV1 G14713A polymorphism in carcinogenesis.

\section{Methods}

\section{Publication search and inclusion criteria}

We searched electronic databases containing PubMed, Chinese National Knowledge Infrastructure, and Chinese Biology Medicine up to June 2015, using the following terms: "caveolin-1 or CAV1" AND "genetic polymorphism or polymorphisms or variant" AND "cancer or carcinoma or tumor". Additional studies were identified by handsearching references of original or review articles on this topic. If data were published in more than one article, only the publication with the largest sample size was included. Studies were selected according to the following criteria: 1) studies should have evaluated the association between CAV1 G14713A polymorphism and cancer susceptibility; 2 ) the type of study design should be a case-control study; and 3 ) studies should have a detailed genotype frequency of cases and controls.

\section{Data extraction}

Two investigators independently screened the studies and extracted the following data from the included studies: first author's name, publication year, ethnicity, cancer type, total number of cases and controls, and genotype distributions in cases and controls. Disagreements were resolved through discussion with another investigator.

\section{Statistical analysis}

Odds ratios (ORs) with corresponding 95\% confidence intervals (CIs) were calculated to assess the strength of associations of $C A V 1$ G14713A polymorphism with cancer susceptibility. ORs were calculated using five genetic models: homozygous (AA vs GG), heterozygous (AG vs GG), dominant $([A A+A G]$ vs $G G)$, recessive (AA vs $[A G+G G])$, and allele contrast (A vs $G$ ). Subgroup analysis was also conducted according to the type of cancer. Heterogeneity among studies was assessed using the $Q$-test and $I^{2}$ statistics. When heterogeneity was considered significant $\left(P_{\text {het }}<0.05\right.$ or $I^{2}>50 \%$ ), a random-effect model was used; otherwise, a fixed-effect model was used. Sensitivity analysis was performed by removing the single studies, one at a time and recalculating the summarized ORs. Potential publication bias of the included studies was assessed by Begg's funnel plots and Egger's test. All $P$-values were two sided, and all analyses were carried out with STATA 12.0 software package (Stata Corporation, College Station, TX, USA).

\section{Results \\ Characteristics of studies and main results}

As shown in Figure 1, we initially extracted 56 articles in relation to the search words. Among them, 12 articles that met the inclusion criteria were included in this study. The principle characteristics of the 12 eligible studies are summarized in Tables 1 and 2. Six studies were conducted on digestive system cancer and six studies on cancer of other systems. The main meta-analysis results and the heterogeneities are shown in Table 3 and Figure 2. In the overall analysis, $C A V 1 \mathrm{G} 14713 \mathrm{~A}$ polymorphism showed a significant association with increased risk of cancer (A vs G: OR $=1.77,95 \% \mathrm{CI}: 1.49-2.10, P_{\text {het }}<0.01 ;[\mathrm{AA}+\mathrm{AG}]$ vs GG: $\mathrm{OR}=2.03,95 \% \mathrm{CI}: 1.64-2.53, P_{\text {het }}<0.01$; AA vs $[\mathrm{AG}+\mathrm{GG}]: \mathrm{OR}=1.72,95 \% \mathrm{CI}: 1.40-2.12, P_{\text {het }}<0.01$; AA vs GG: OR =2.24, 95\% CI: 1.69-2.98, $P_{\text {het }}<0.01$; AG vs GG: OR $=1.98,95 \%$ CI: $\left.1.62-2.41, P_{\text {het }}<0.01\right)$. In addition, the results of stratified analysis by tumor type suggested that CAV1 G14713A polymorphism was associated with an increased risk of digestive system cancer (A vs G: OR $=2.02,95 \%$ CI: $1.75-2.33, P_{\text {het }}=0.03$; $[\mathrm{AA}+$ AG] vs GG: OR $=2.40,95 \%$ CI: $1.94-2.98, P_{\text {het }}<0.01 ; A A$ vs $[\mathrm{AG}+\mathrm{GG}]$ : $\mathrm{OR}=2.01,95 \% \mathrm{CI}: 1.68-2.40, P_{\text {het }}=0.83$;

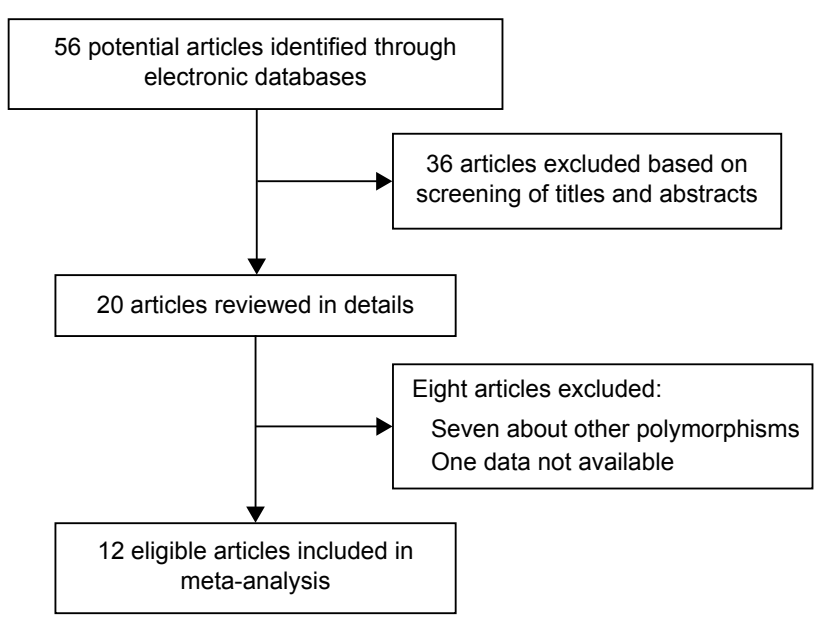

Figure I Flow-chart of included studies for this meta-analysis. 
Table I Main characteristics of included studies

\begin{tabular}{|c|c|c|c|c|}
\hline First author & Ethnicity & Cancer type & Case & Control \\
\hline Wang et $\mathrm{al}^{8}$ & Asian & Esophageal squamous cell carcinoma (digestive system cancer) & 427 & 427 \\
\hline Zhang et al ${ }^{9}$ & Asian & Gastric cancer (digestive system cancer) & 412 & 412 \\
\hline Lin et $\mathrm{al}^{10}$ & Asian & Gastric cancer (digestive system cancer) & 358 & 358 \\
\hline Wang et al" & Asian & Leukemia (other system cancer) & 266 & 266 \\
\hline Hsu et $\mathrm{al}^{12}$ & Asian & Hepatocellular carcinoma (digestive system cancer) & 298 & 298 \\
\hline Chang et $\mathrm{al}^{13}$ & Asian & Upper urothelial tract cancer (other system cancer) & 218 & 580 \\
\hline Wu et $\mathrm{al}^{14}$ & Asian & Prostate cancer (other system cancer) & 250 & 500 \\
\hline Tsou et al ${ }^{15}$ & Asian & Nasopharyngeal carcinoma (other system cancer) & 176 & 176 \\
\hline Liu et $\mathrm{a}^{16}$ & Asian & Breast cancer (other system cancer) & 1,232 & 1,232 \\
\hline Bau et $\mathrm{al}^{17}$ & Asian & Oral cancer (digestive system cancer) & 620 & 620 \\
\hline Bau et $\mathrm{al}^{18}$ & Asian & Bladder cancer (other system cancer) & 375 & 375 \\
\hline Yang et $a^{19}$ & Asian & Colorectal cancer (digestive system cancer) & 362 & 362 \\
\hline
\end{tabular}

Table 2 Allele frequency and genotype distributions of cases and controls in included studies

\begin{tabular}{|c|c|c|c|c|c|c|c|c|c|c|c|c|c|c|}
\hline \multirow[t]{2}{*}{ First author } & \multicolumn{7}{|c|}{ Case (G I 47 I 3A) } & \multicolumn{7}{|c|}{ Control (G I 47 I3A) } \\
\hline & GG & GA & AA & $\mathbf{G A}+\mathbf{A A}$ & $\mathbf{G G}+\mathbf{G A}$ & G & A & GG & GA & AA & $\mathbf{G A}+\mathbf{A A}$ & $\mathbf{G G}+\mathbf{G A}$ & G & A \\
\hline Wang et $\mathrm{al}^{8}$ & 212 & 168 & 47 & 215 & 380 & 592 & 262 & 281 & 123 & 23 & 146 & 404 & 685 & 169 \\
\hline Zhang et al ${ }^{9}$ & 148 & 175 & 89 & 264 & 323 & 471 & 353 & 265 & 104 & 43 & 147 & 369 & 634 & 190 \\
\hline Lin et $\mathrm{a}^{10}$ & 172 & 136 & 50 & 186 & 308 & 480 & 236 & 235 & 90 & 33 & 123 & 325 & 560 & 156 \\
\hline Wang et al" & 110 & 106 & 50 & 156 & 216 & 326 & 206 & 176 & 67 & 23 & 90 & 243 & 419 & 113 \\
\hline Hsu et $\mathrm{al}^{12}$ & 162 & 96 & 40 & 136 & 258 & 420 & 176 & 196 & 77 & 25 & 102 & 273 & 469 & 127 \\
\hline Chang et $\mathrm{al}^{13}$ & 118 & 72 & 28 & 100 & 190 & 308 & 128 & 377 & 146 & 57 & 203 & 523 & 900 & 260 \\
\hline Wu et al ${ }^{14}$ & $|5|$ & 72 & 27 & 99 & 223 & 374 & 126 & 330 & 129 & $4 I$ & 170 & 459 & 789 & 211 \\
\hline Tsou et al ${ }^{15}$ & 113 & 47 & 16 & 63 & 160 & 273 & 79 & 116 & 45 & 15 & 60 & 161 & 277 & 75 \\
\hline Liu et $\mathrm{al}^{16}$ & 704 & 409 & 119 & 528 & 1,113 & 1,817 & 647 & 801 & 311 & 120 & 431 & 1,112 & 1,913 & 551 \\
\hline Bau et $\mathrm{al}^{17}$ & 238 & 279 & 103 & 382 & 517 & 755 & 485 & 397 & 167 & 56 & 223 & 564 & 961 & 279 \\
\hline Bau et $\mathrm{al}^{18}$ & 144 & 160 & 71 & 231 & 304 & 448 & 302 & 245 & 96 & 34 & 130 & 341 & 586 & 164 \\
\hline Yang et al ${ }^{19}$ & 135 & 165 & 62 & 227 & 300 & 435 & 289 & 234 & 96 & 32 & 128 & 330 & 564 & 160 \\
\hline
\end{tabular}

Table 3 Meta-analysis of caveolin-I GI47I3A polymorphism and cancer susceptibility in Asian population

\begin{tabular}{|c|c|c|c|c|c|c|c|c|c|c|c|c|}
\hline \multirow[t]{2}{*}{ Variables } & \multicolumn{4}{|c|}{$\begin{array}{l}\text { Allele contrast } \\
\text { (A vs } G \text { ) }\end{array}$} & \multicolumn{4}{|c|}{$\begin{array}{l}\text { Dominant contrast } \\
([A A+A G] \text { vs } G G)\end{array}$} & \multicolumn{4}{|c|}{$\begin{array}{l}\text { Recessive contrast } \\
\text { (AA vs }[A G+\text { GG]) }\end{array}$} \\
\hline & $P^{2}$ & $\boldsymbol{P}_{\text {het }}$ & $P_{z}$ & OR $(95 \% \mathrm{Cl})$ & $I^{2}$ & $\boldsymbol{P}_{\text {het }}$ & $P_{z}$ & OR (95\% Cl) & $I^{2}$ & $P_{\text {het }}$ & $P_{z}$ & OR $(95 \% \mathrm{Cl})$ \\
\hline All & $86 \%$ & $<0.01$ & $<0.01$ & $1.77(1.49-2.10)$ & $86 \%$ & $<0.01$ & $<0.01$ & $2.03(1.64-2.53)$ & $61 \%$ & $<0.01$ & $<0.01$ & $1.72(1.40-2.12)$ \\
\hline $\begin{array}{l}\text { Digestive } \\
\text { system cancer }\end{array}$ & $61 \%$ & 0.03 & $<0.01$ & $2.02(1.75-2.33)$ & $71 \%$ & $<0.01$ & $<0.01$ & $2.40(1.94-2.98)$ & $0 \%$ & 0.83 & $<0.01$ & $2.01(1.68-2.40)$ \\
\hline \multirow[t]{2}{*}{$\begin{array}{l}\text { Other cancer } \\
\text { types }\end{array}$} & $88 \%$ & $<0.01$ & $<0.01$ & $1.55(1.18-2.03)$ & $86 \%$ & $<0.01$ & $<0.01$ & $1.72(1.25-2.36)$ & $70 \%$ & 0.01 & 0.02 & $1.49(1.06-2.10)$ \\
\hline & \multicolumn{4}{|c|}{ Homozygous contrast (AA vs GG) } & \multicolumn{4}{|c|}{ Heterozygous contrast (AG vs GG) } & & & & \\
\hline All & $78 \%$ & $<0.01$ & $<0.01$ & $2.24(1.69-2.98)$ & $79 \%$ & $<0.01$ & $<0.01$ & $1.98(I .62-2.4 I)$ & & & & \\
\hline $\begin{array}{l}\text { Digestive } \\
\text { system cancer }\end{array}$ & $14 \%$ & 0.32 & $<0.01$ & $2.84(2.36-3.42)$ & $68 \%$ & 0.01 & $<0.01$ & $2.30(1.84-2.88)$ & & & & \\
\hline $\begin{array}{l}\text { Other cancer } \\
\text { types }\end{array}$ & $81 \%$ & $<0.01$ & 0.01 & $1.81(1.16-2.84)$ & $78 \%$ & $<0.01$ & $<0.01$ & $1.69(1.28-2.24)$ & & & & \\
\hline
\end{tabular}

Abbreviations: $P_{\text {het }}, P$-value of heterogeneity test; $P_{Z}, P$-value of $Z$-test; $O R$, odds ratio; $C l$, confidence interval. 

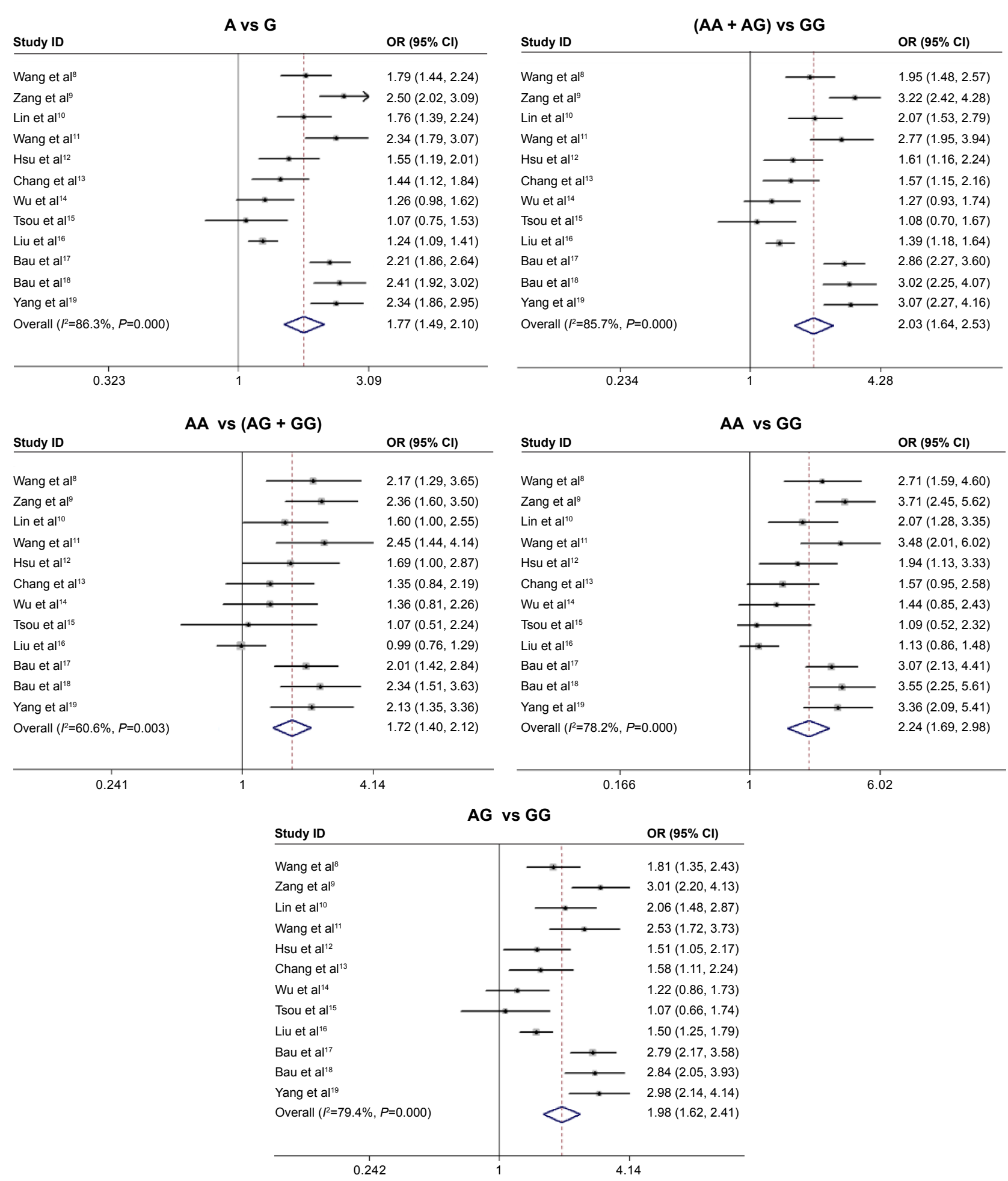

Figure 2 Forest plots representing the pooled results of ORs for the association between CAVI GI47I3A polymorphism and overall cancer risk. Note: Weights are from random effects analysis.

Abbreviations: OR, odds ratio; $\mathrm{Cl}$, confidence interval; CAVI, caveolin-I.

AA vs GG: $\mathrm{OR}=2.84,95 \%$ CI: $2.36-3.42, P_{\text {het }}=0.32 ;$ AG vs GG: $\left.\mathrm{OR}=2.30,95 \% \mathrm{CI}: 1.84-2.88, P_{\text {het }}=0.01\right)$ and cancer of other systems (A vs G: OR $=1.55,95 \% \mathrm{CI}$ : $1.18-2.03, P_{\text {het }}<0.01 ;[\mathrm{AA}+\mathrm{AG}]$ vs GG: OR $=1.72,95 \%$
CI: $1.25-2.36, P_{\text {het }}<0.01$; AA vs $[\mathrm{AG}+\mathrm{GG}]: \mathrm{OR}=1.49$, 95\% CI: $1.06-2.10, P_{\text {het }}=0.01 ;$ AA vs GG: OR $=1.81,95 \%$ CI: $1.16-2.84, P_{\text {het }}<0.01$; AG vs GG: OR $=1.69,95 \%$ CI: $\left.1.28-2.24, P_{\text {het }}<0.01\right)$. 

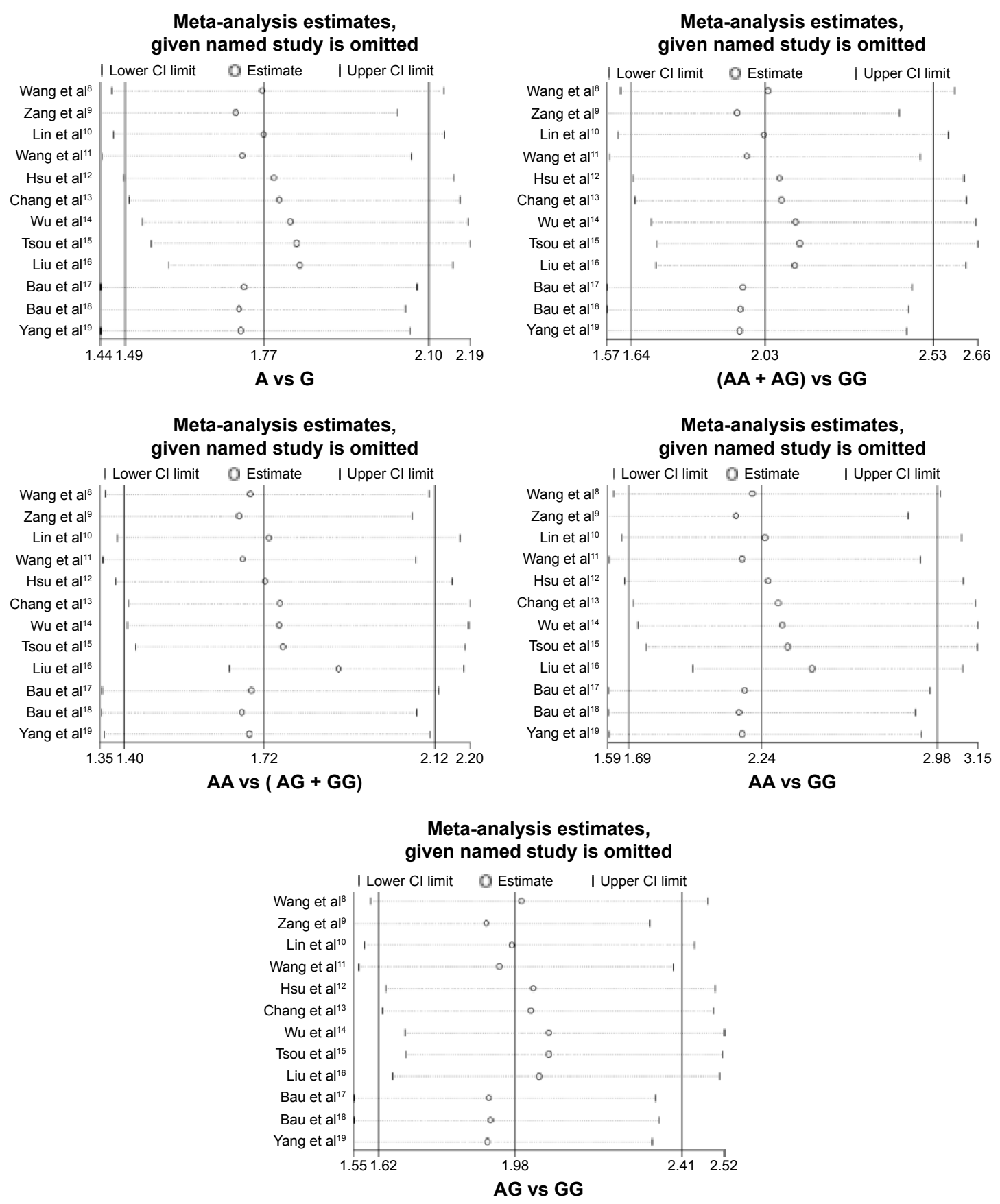

Figure 3 Sensitivity analysis results of the association between CAVI GI47I3A polymorphism and overall cancer risk. Abbreviations: $\mathrm{Cl}$, confidence interval; OR, odds ratio; CAVI, caveolin-I.

\section{Sensitivity analysis and publication bias}

A sensitivity analysis was performed by omitting every study in turn to check the influence of the removed data. Pooled estimates for all genetic models were insensitive to the removal of individual study, and the corresponding pooled ORs were not substantially altered, suggesting that our results were stable and reliable (Figure 3). Both Begg's funnel plots and Egger's test were performed to examine the underlying publication bias (Figure 4). The symmetrical funnel plots and $P$-value $>0.05$ for Egger's test indicated no publication bias in this meta-analysis.

\section{Discussion}

CAV1 is the major structural protein in caveolae and consists of 178 amino acids; it has been identified as a tumor suppressor in $1989 .{ }^{20} \mathrm{CAV} 1$ plays an important role in many signaling pathways, molecular transport, and cellular proliferation and differentiation, which are potentially involved in the 


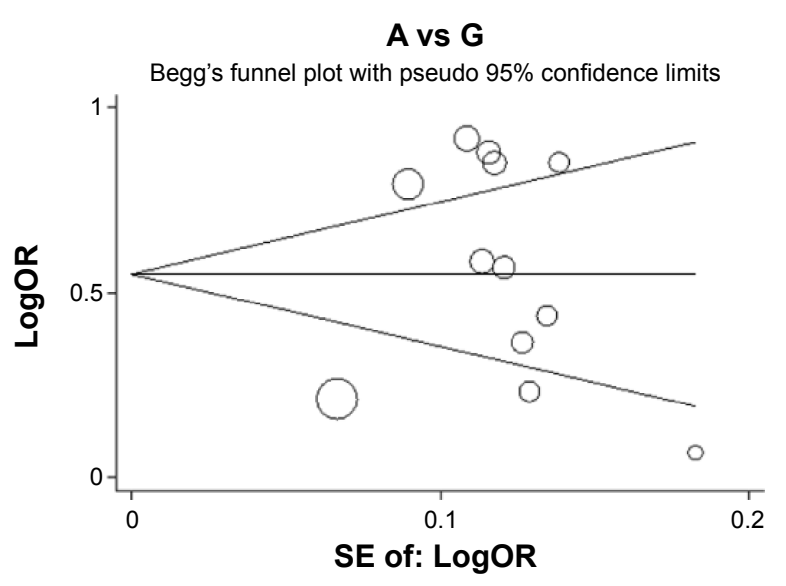

AA vs (AG + GG)

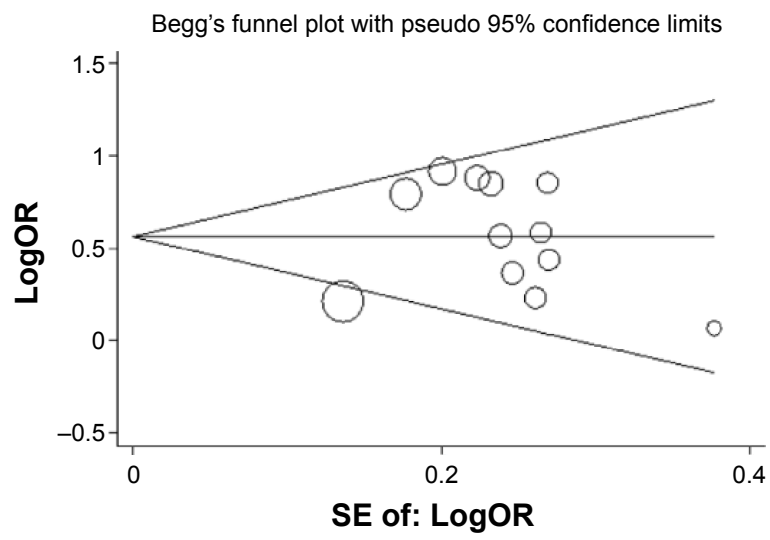

(AA + AG) vs GG

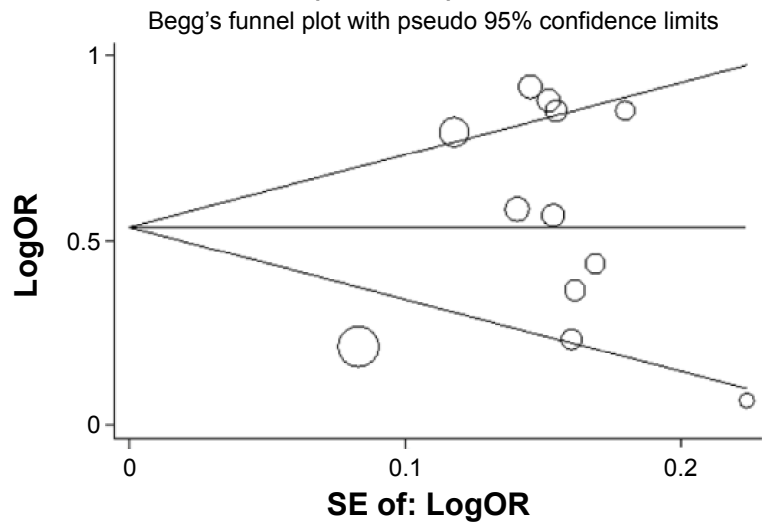

AA vs GG

Begg's funnel plot with pseudo 95\% confidence limits

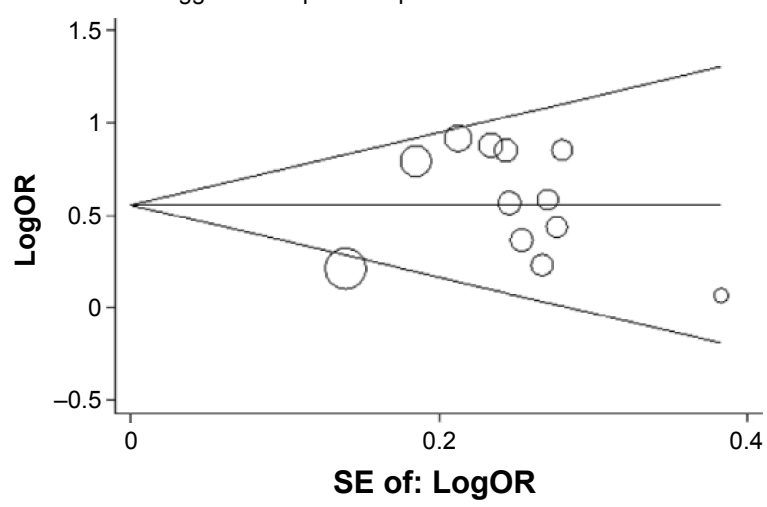

AG vs GG

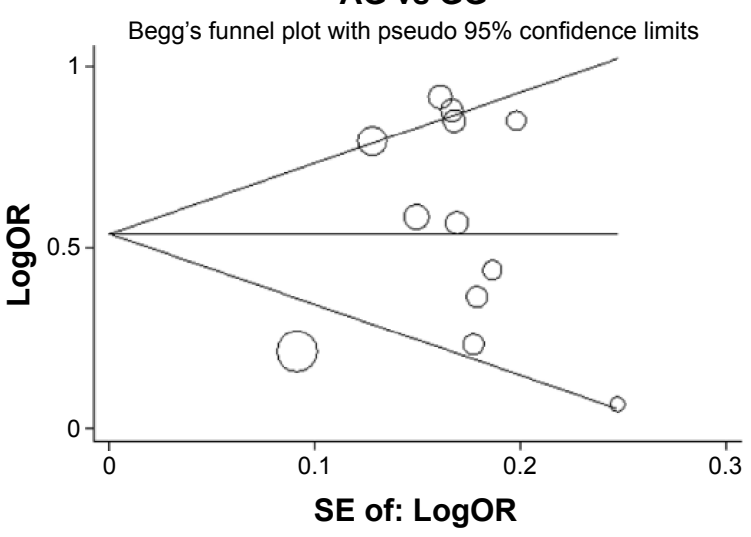

Figure 4 Begg's funnel plots of the association between CAVI GI47I3A polymorphism and overall cancer risk. Abbreviations: SE, standard error of the logOR; logOR, natural logarithm of the OR; OR, odds ratio; CAVI, caveolin-I.

development of human cancer. ${ }^{21}$ The association of CAV1 G14713A polymorphism with cancer risk has been widely reported, but results are conflicting. For example, some studies indicated that $C A V 1$ G14713A polymorphism was associated with cancer risk, such as esophageal squamous cell carcinoma, gastric cancer, hepatocellular carcinoma, and breast cancer., ${ }^{90,12,16}$ Other studies demonstrated that CAV1 G14713A polymorphism was not associated with the risk of cancer, including prostate cancer and nasopharyngeal carcinoma. ${ }^{14,15}$ To provide a more detailed overview of the association, five genetic models were used in the current metaanalysis. To our knowledge, this is the first meta-analysis of the association between $C A V 1$ G14713A polymorphism and cancer risk, and the results suggested that CAV1 G14713A polymorphism increased the risk of cancer. In the subgroup analysis by tumor type, $C A V 1$ G14713A polymorphism was significantly associated with an increased risk of digestive system cancer and cancer of other systems.

Our meta-analysis had some advantages. For instance, we strictly obeyed the inclusion and exclusion criteria to 
reduce selection bias. Furthermore, there was no evidence of publication bias in this meta-analysis, and the sensitivity analysis confirmed the reliability and stability of the results. Despite these advantages, limitations should be considered when interpreting our results. First, our results were based on unadjusted estimates. More analyses that are precise can be conducted if individual data, including age and sex, were available. Second, all published studies were based on Asian populations. Therefore, the results of this meta-analysis may be applicable to the specified ethnicity alone.

\section{Conclusion}

The present study demonstrated that CAV1 G14713A polymorphism might contribute to individual susceptibility to cancer. However, further well-designed studies are required to evaluate this association.

\section{Acknowledgment}

This work was supported by the National Nature Science Foundation in China (NSFC) (81560403 to J Tang).

\section{Disclosure}

The authors report no conflicts of interest in this work.

\section{References}

1. Jemal A, Bray F, Center MM, Ferlay J, Ward E, Forman D. Global cancer statistics. CA Cancer J Clin. 2011;61(2):69-90.

2. Gao X, Wang J, Wang W, Wang M, Zhang J. eNOS genetic polymorphisms and cancer risk: a meta-analysis and a case-control study of breast cancer. Medicine (Baltimore). 2015;94(26):e972.

3. Xu M, Qiang F, Gao Y, et al. Evaluation of a novel functional singlenucleotide polymorphism (rs35010275 G >C) in MIR196A2 promoter region as a risk factor of gastric cancer in a Chinese population. Medicine (Baltimore). 2014;93(26):e173.

4. Gao X, Zhang S, Zhu Z. Lysyl oxidase rs 1800449 polymorphism and cancer risk among Asians: evidence from a meta-analysis and a case-control study of colorectal cancer. Mol Genet Genomics. 2015;290(1):23-28.

5. Goetz JG, Lajoie P, Wiseman SM, Nabi IR. Caveolin-1 in tumor progression: the good, the bad and the ugly. Cancer Metastasis Rev. 2008; 27(4):715-735.
6. Burgermeister E, Xing X, Röcken C, et al. Differential expression and function of caveolin-1 in human gastric cancer progression. Cancer Res. 2007;67(18):8519-8526.

7. Salatino M, Beguelin W, Peters MG, et al. Progestin-induced caveolin-1 expression mediates breast cancer cell proliferation. Oncogene. 2006;25(59):7723-7739.

8. Wang S, Zhang C, Liu Y, Xu C, Chen Z. Functional polymorphisms of caveolin-1 variants as potential biomarkers of esophageal squamous cell carcinoma. Biomarkers. 2014;19(8):652-659.

9. Zhang Y, Hu XJ, Zhang LL, et al. Interaction among caveolin-1 genotypes (rs3807987/rs7804372), H. pylori infection, and risk of gastric cancer in a Chinese population. Tumour Biol. 2014;35(2):1511-1516.

10. Lin CH, Lin CC, Tsai CW, Chang WS, Yang CW, Bau DT. Association of caveolin-1 genotypes with gastric cancer in Taiwan. Anticancer Res. 2014;34(5):2263-2267.

11. Wang CH, Lai YL, Chang WS, et al. Significant association of caveolin-1 single nucleotide polymorphisms with childhood leukemia in Taiwan. Cancer Genomics Proteomics. 2013;10(2):75-79.

12. Hsu CM, Yang MD, Tsai CW, et al. The contribution of caveolin-1 genotype and phenotype to hepatocellular carcinoma. Anticancer Res. 2013;33(2):671-677.

13. Chang WS, Lin SS, Li FJ, et al. Significant association of caveolin-1 (CAV1) genotypes with upper urothelial tract cancer. Anticancer Res. 2013;33(11):4907-4912.

14. Wu HC, Chang CH, Tsou YA, Tsai CW, Lin CC, Bau DT. Significant association of caveolin-1 (CAV1) genotypes with prostate cancer susceptibility in Taiwan. Anticancer Res. 2011;31(2):745-749.

15. Tsou YA, Tsai CW, Tsai MH, et al. Association of caveolin-1 genotypes with nasopharyngeal carcinoma susceptibility in Taiwan. Anticancer Res. 2011;31(10):3629-3632.

16. Liu LC, Su CH, Wang HC, et al. Significant association of caveolin-1 (CAV1) genotypes with breast cancer in Taiwan. Anticancer Res. 2011; 31(10):3511-3515.

17. Bau DT, Tsai MH, Tsou YA, et al. The association of caveolin-1 genotypes with oral cancer susceptibility in Taiwan. Ann Surg Oncol. 2011; 18(5):1431-1438.

18. Bau DT, Chang CH, Tsai RY, et al. Significant association of caveolin-1 genotypes with bladder cancer susceptibility in Taiwan. Chin J Physiol. 2011;54(3):153-160.

19. Yang MD, Tsai RY, Liu CS, et al. Association of caveolin-1 polymorphisms with colorectal cancer susceptibility in Taiwan. World J Gastrointest Oncol. 2010;2(8):326-331.

20. Glenney JR Jr. Tyrosine phosphorylation of a $22-\mathrm{kDa}$ protein is correlated with transformation by Rous sarcoma virus. J Biol Chem. 1989; 264(34):20163-20166.

21. Yang G, Truong LD, Wheeler TM, Thompson TC. Caveolin-1 expression in clinically confined human prostate cancer: a novel prognostic marker. Cancer Res. 1999;59(22):5719-5723.
OncoTargets and Therapy

\section{Publish your work in this journal}

OncoTargets and Therapy is an international, peer-reviewed, open access journal focusing on the pathological basis of all cancers, potential targets for therapy and treatment protocols employed to improve the management of cancer patients. The journal also focuses on the impact of management programs and new therapeutic agents and protocols on

\section{Dovepress}

patient perspectives such as quality of life, adherence and satisfaction. The manuscript management system is completely online and includes a very quick and fair peer-review system, which is all easy to use. Visit http://www.dovepress.com/testimonials.php to read real quotes from published authors. 